\title{
Troubles with Biocitizenship?
}

\section{ALEXANDRA PLOWS \& PAULA BODDINGTON}

\begin{abstract}
Genetic and other biotechnologies are starting to impact significantly upon society and individuals within it. Rose and Novas draw on an analysis of many patient groups to sketch out the broad notion of biocitizenship as a device for describing how the empowered and informed individual, group or network can engage with bioscience. In this paper, we examine critically the notion of biocitizenship, drawing on both sociological fieldwork that grounds the debate in the views of a large and varied group of concerned actors. Using work within green politics, we identify shortcomings in the concept of biocitizenship as it has so far been explicated. The value assumptions lying behind an account of biocitizenship, and its tendency to see issues through a reductive lens, are examined. Alternative views of values and goals, which may undermine any alleged rights and duties, are explored using interviews and other ethnographic data that illustrates the complexity of the terrain. The reductive lens of biocitizenship is explored through contrast with the wider scope of concerns emanating from various sources, including many within green politics. If such complexities are not recognised, there is a danger that a concept of biocitizenship may serve to create and amplify inequalities. Problems with identity issues are key: the construction of identity is complex and many groups are explicitly rejecting the 'biological' label. We discuss the multiple relations of citizens with the biotech and pharmaceutical industries. Arguably, existing inequalities in power relationships, exploitation, commodification and ownership patterns are being perpetuated in novel ways through the new biosciences. We pose the question of whether it is possible to construct a concept of biocitizenship that overcomes these problems.
\end{abstract}

\section{Introduction}

Biotechnology, including genetic technology and information, is having a significant and growing impact upon society and individuals. One concept that has been used to provide a framework for examining this impact is that of biocitizenship. As explicated by Rose and Novas, ${ }^{1}$ biocitizenship can be seen as one account of the many versions of citizenship currently under discussion. Their concept needs to be examined against other contemporary citizenship debates. In this paper we examine critically Rose and Novas's notion of biocitizenship and suggest that it covers such complex and contested ground that its usefulness in advancing citizenship debates is in question. Indeed, there is a danger that it might act to obscure key debates which require urgent attention. The 'bio' part of biocitizenship is in constant danger of being given a reductive gloss, which has consequences for how citizenship issues are identified and approached. It is important to consider the danger that a notion of biocitizenship such as Rose and Novas's might be co-opted to the service of biotechnology; why this is seen as problematic will be discussed. We end by posing the question of whether a notion of biocitizenship that fruitfully enhances democratic citizenship debate can be constructed. 
The paper draws on qualitative ethnographic data collated between 2003 and 2006 amongst UK publics engaging with human genetic/genomic technologies. ${ }^{2}$ Ethnographic 'snapshots' were taken of emergent and multiple networks of publics engaging over a wide variety of issues, enabling a broad overview of key actors, claims (frames) and mobilisation patterns. ${ }^{3}$ Case study work focused in more detail amongst latent networks of actors predisposed to articulate oppositional frames, ${ }^{4}$ exploring their emergent engagement with medical genetics/genomics. ${ }^{5}$ This coauthored paper represents an interdisciplinary collaboration between social science and philosophy, with the intention of highlighting the relevance of some different bodies of academic thought to contemporary Science and Technology Studies (STS) debates on (bio)science, knowledge and public engagement. The notion of biocitizenship arises from long established debates around biopolitics, as well as the historical development of various conceptions of citizenship. Space does not permit a full examination of these issues, although they inform our critique of Rose and Novas's explication of biocitizenship. There are many ways of approaching debates around citizenship; here we draw upon some key literature in some other academic disciplines, specifically from green politics, which we believe relates well to the debate on (bio)citizenship, and which, as we hope to show, provides one useful frame for illuminating some of the key problems with the concept as it currently stands.

\section{Current citizenship debates}

Contemporary accounts of, and debates about, the nature and the constituency of 'citizenship' are of the Zeitgeist in a number of different academic domains, and are of course well established within STS, where they are linked to debates on expertise and knowledge production. (See, for example, Irwin, ${ }^{6}$ Irwin and Michael, ${ }^{7}$ and their discussions of 'scientific citizens' in particular.) In the sphere of 'green politics', theorists such as Fischer, ${ }^{8}$ Dobson, ${ }^{9}$ Barry ${ }^{10}$ and Hayward ${ }^{11}$ are engaging with the concept of citizenship, with the aim of firming up political theory for civil society environmental 'best practice' in an age of globalisation. ${ }^{12}$ They are debating concepts of emergent global 'civil society' engagement as a response to globalisation and the challenges of sustainable development, even as these social networks are evolving in real time. ${ }^{13}$ A recent debate in the journal Environmental Politics ${ }^{14}$ concerns Andrew Dobson's conceptions of ecological citizenship, and whether they are a politically robust theoretical principle. Tim Hayward contends that Dobson's concepts inform, rather than replace, a 'traditional' political conceptualisation of citizenship. Dobson, for his part, argues that the nature of politics, and of a political 'polity', 'membership' of which infers citizenship, need to be conceptualised beyond the confines of a nationstate. Furthermore, he sees ecological citizenship as a practice, not a status. Tellingly for issues of inequality, which we argue are a major problem with biocitizenship, justice is a core principle of ecological citizenship for Dobson. Rights and duties of ecological citizenship are points of debate for both Hayward and Dobson.

The existence and nature of the rights, duties and even membership of the category of citizen, is thus up for grabs not only within disciplines, but between them. There are multiple and overlapping citizenships, and there will inevitably be conflict and contest, as well as convergences, within and between citizenships. Therefore, we need to ask how much the label of 'bio' citizen adds to citizenship debates and to our understanding of our relationship to biotechnology. 
Between them, 'green' political theorists like Barry, Hayward and Dobson have developed a conceptualisation of citizenship which, importantly, focuses on issues of social justice in an age of globalisation, where environmental risks, social inequities, and attendant health risks, are generally, but far from exclusively, borne by the global poor. ${ }^{15}$ Ecosystem and human health have comprised an explicit frame developed within the core concept of environmental sustainability and citizenship. Thus, the 'green' environmental literature has made a significant contribution to the 'red' health literature, in terms of the clear links environmental theorists ${ }^{16}$ explicitly make between, for example, environmental degradation and pollution, and health, ${ }^{17}$ and also because, as Dobson argues in the pages of Environmental Politics, "justice is the virtue currency of ecological citizenship". ${ }^{18}$ This literature examines in detail the key frames of environmental social justice-orientated health movements, such as those identified by Brown and Zavestoski. ${ }^{19}$ Such movements mobilise over health concerns, but consistently have accompanying core frames relating to social justice and environmental issues, for example over pollution grievances.

In the 2004 special edition on health social movements in the journal Sociology of Health and Illness, the editors, Brown and Zavestoski, give several examples of such social movements, such as women's health movements mobilising over breast cancer. ${ }^{20}$ Many other global examples exist, including locals questioning the 'coincidence' of leukaemia clusters at Sellafield, 'Love canal' in the USA, and the mobilisation of Bhopal victims and their supporters. Tellingly, Rose and Novas offer the mobilisation of similar groups over the Chernobyl disaster as an example of how citizens understand themselves as biological citizens. ${ }^{21}$ To frame these mobilising actors as 'biocitizens' would be to emphasise one aspect of their identity. Brown and Zavestoski themselves emphasise that health is the core mobilising frame for several of these movements, but in truth the 'bio' prefix would mask the accompanying emphasis on social and environmental issues clearly foregrounded in much movement discourse.

As we will argue, of the many different types of health groups and patient groups, biological identity will be a core mobilising factor (or issue to be identified with) for some, but not for others. Brown and Zavestoski themselves identify multiple typologies of health and patient groups that may conflict and overlap - the boundaries between identity types are blurred. It is perhaps a truism to state that all social actors as individuals consist of fluid and multiple identities, and that how one chooses to frame or present oneself, or how one is presented by others, is context-dependant. The notions of 'biocitizens' and/or 'ecological citizens' are crucial as there are important divergences in terms of emphasis, social construction, and potential solutions to identified problems, implied by the different prefixes. It is of concern to us that Rose and Novas, engaging with the spheres of health and medicine, are developing conceptions of biocitizenship in seeming isolation from the well developed debates on citizenship, justice and globalisation, which include debates on health and science, which have been occurring within 'green' political thought for some time. We argue that the types of issues raised by the 'green' literature illustrate core problems that we identify with Rose and Novas's concept of biocitizenship. 
Moreover, the rights and duties of any type of citizen are still going to be defined mostly by those with power; and they can consist of a variable and wide range. Through invoking a discourse of citizenship, and constructing contemporary meanings of it, Rose and Novas, Dobson, Barry et al are all engaging in important work in terms of identifying the need for greater civil society participation in all sorts of life practices, and championing those who do engage. However, conferring different types of rights, let alone duties, on civil society, which are invoked by concepts of citizenship, is extremely problematic when it comes to the policy definition of what these rights and duties are, and when their implications are examined in detail. In the context of medical health, the focus of this paper, various players in the public domain with specific ideological positions, such as outspoken bioethicists with broadly utilitarian agendas, and/or those with vested interests, ${ }^{22}$ are currently invoking the duties of citizenship; they are colonising a new arena of global civil society, using a discourse of citizenship to push a certain course of action before civil society has had a chance to even have a debate. For instance, John Harris has recently argued that "[b]iomedical research is so important that there is a positive moral obligation to pursue it and to participate in it". ${ }^{23}$ We suggest that the urgency of debates around the construction of meaning make Jasanoff's notion of 'epistemic citizenship' a more useful construct for articulating debates about the impact of biotechnology, a complex field where multiple struggles for meaning are being fought, although only some are being heard clearly. ${ }^{24}$

\section{Biocitizenship}

Rose and Novas make a general claim that "specific biological presuppositions, explicitly or implicitly, have underlain many citizenship projects, shaped conceptions of what it means to be a citizen, and underpinned distinctions between actual, potential, troublesome and impossible citizens". ${ }^{25}$ They use 'biocitizenship' broadly, and descriptively, to "encompass all those citizenship projects that have linked their conceptions of citizens to beliefs about the biological existence of human beings, as individuals, as families and lineages, as communities, as population and races, and as a species." ${ }^{26}$ Citizens may be 'made up' from above by governments' particular practices that relate to corporeality or biology in some way. And biological notions, they argue, have in the past, and increasingly so, shaped citizens' selfunderstanding. ${ }^{27}$

From this broad understanding they go on to explore how a notion of biocitizenship can be used to understand developing trends, such as their claim that "collectivities organised around specific biomedical classifications are increasingly significant". ${ }^{28}$ However, we consider that their explication of this concept, including the cast of the particular examples they use to illustrate it, means that their development of it incorporates clear normative implications, fostering particular relationships with biotechnology and potentially helping to forge new, and deepen existing, inequalities. It must be noted that they emphasise initially that "not all have equal citizenship in this new biological age". ${ }^{29}$ Rose and Novas refer here specifically to problems with bioprospecting and biopiracy. In this paper we argue that many more examples of troubling inequality need scrutiny, and that many of Rose and Novas's other examples act to divert attention away - with troubling implications - from inequalities sheltering under the roof of biocitizenship as they define and subsequently explicate it. 
Questions of human value and human worth and biological responsibilities are played out in different ways in relation to biocitizenship. For Rose and Novas, this citizenship is inherently active, and they discuss biocitizenship in terms of ethical demands that biological senses of identification and affiliation enable, including rights, duties, responsibilities, prudence and choice. In fact, they claim, "judgments of value concerning certain features of bodies and capacities of citizens have become inescapable". ${ }^{30}$ We go on critically to examine these 'judgements of value', giving some examples of how they are being constructed and apportioned to 'biocitizens', and demonstrating how the term 'biocitizenship', unless subjected to more critical engagement, could foster too sympathetic a reading of this process. The "distinctions between actual, potential, troublesome and impossible citizens" can be drawn and understood in many different ways.

\section{'Making up' biocitizens: Rose and Novas's examples of patient groups}

Rose and Novas illustrate how biological categories are forming identities and groupings for activism and for 'making up' categories of citizens in relation to the authorities with the use of various examples. We begin our critique with an examination of those examples, enriching the sample from our own ethnographic data, and showing how their ethnographic examples act to skew the biocitizenship agenda. This is largely due to the fact that they do not emphasise sufficiently that their data primarily represent a certain type of 'biocitizen' and fail to identify the range of other emergent groups and networks exercising citizenship stakes in this arena.

Following on from this, careful examination of Rose and Novas's use of the term 'biological', and the way in which identities of various groupings are formed, leads us to see that, in this context, to prioritise the biological is often ipso facto to produce a reductive account of problems, solutions and identities. ${ }^{31}$ This potential reductionism may seduce us into a narrow outlook; at the same time, the 'biological' label can be applied very widely to a host of divergent issues and divergent understandings to the extent that it obscures salient distinctions and real disputes over goals and values, and hinders our ability to think critically and robustly about the impact of biotechnology on humanity. As we shall argue, Rose and Novas tend to identify as biological certain membership categories even though the rejection of biology is a salient organising feature for some, and select examples of mobilisation which reinforce the 'future promise $^{, 32}$ framing of biotechnology rather than ones which seek to critique and curtail it.

Moreover, they locate the patient groups to which they refer as examples of 'informational biocitizenship', involving specific scientific and medical knowledge of one's condition. ${ }^{33}$ However, there is a grave danger that this might overlook real issues and disputes about the veracity and salience of this 'scientific and medical knowledge'. Thus, we argue, the way in which Rose and Novas have so far explicated the idea of biocitizenship acts to present it in a certain, implicitly favourable, relation to biotechnology industry and biotechnological knowledge. It remains to be seen whether some notion of biocitizenship might be possible which leaves more space for open debates about the directions and benefits of biotechnology. Such debates on the nature and implications of the 'bio-economy' incorporate other familiar issues such as 
expertise, how knowledges are defined and found to be of value. As we will demonstrate, these are core themes within many civil society groups and networks whose voices are often misheard, if they are heard at all. Such issues are, to reiterate, well debated within the breadth of 'citizenship' literature highlighted earlier.

Thus the multiple debates in the context of bioscience and health consistently highlight how different actors construct multiple meanings of words (self, health, choice, rights, knowledge etc) and how certain words come to be used in the first place. To reiterate, by grappling with the nature of knowledge and the values trajectories, which different meanings (ie. different knowledge bases) provide, Jasanoff's conceptualisation of 'epistemic citizenship' could be understood to be of perfect relevance for global civil society's engagement with bio-science in the 'knowledge economy'.

Rose and Novas draw on certain key examples of the empowered, informed patientas-consumer (group, network, etc) - an engaged, mobilising actor in the bioeconomy and engaging with health issues and bioscience. There is no doubt that this is an important emergent social reality. Likewise, Brown and Zavestoski delineate various cross-cutting types of 'health social movement', from 'embodied health movements' seeking to assert their own 'embodied expertise' in relation to their own disease status, to what they term 'constituency-based health movements' focusing more on equity and access issues. ${ }^{34}$

Rose and Novas discuss what they call the "proliferation of biosocial communities", such as those mobilising around manic depression. But tellingly, this particular form of depression is one for which a biological origin is more strongly accepted than is the case with other forms. Their discussion of the Prozac website ${ }^{35}$ talks of how it fosters an active aspect of biological citizenship. Many pharmaceutical companies have strong links with patient groups; websites often contain links to these. But these links are to patient groups that tend to lobby for greater access to drugs and to pharmaceutical based research. The Prozac website does not give links to patient groups mobilising around litigation concerning alleged adverse effects of Prozac or of its alleged overprescription (eg, Prozac Survivor). ${ }^{36,37}$ Moreover, a recent report by Consumers International criticises drug companies for misleading consumers, and cites the sponsoring of patient groups funding disease awareness campaigns as a new technique in their armoury of marketing strategies. ${ }^{38,39}$

Crucially for questions of the labelling of 'bio' citizenship, many such patient groups consider alternatives to biological accounts of depression. Additionally, the very disease categories around which identity categories may coalesce or emerge themselves come under scrutiny. As one example of how new biological languages are 'making up citizens', Rose and Novas cite the woman with pre-menstrual dysphoric disorder. But there are those who question the construction of this very disorder, and, it is worth saying, many other disorders, especially psychiatric ones. ${ }^{40}$ This is to say more than simply that such disorders are social constructions; it is to question the power base of such constructions. Such concerns were raised by some of our interviewees:

'[W]e have good evidence of them inventing symptoms...The one which always comes to mind is female sexual dysfunction...they 
[pharmaceutical companies] have this way of saying that actually we can cure that. Well, there might be some aspect of that but... in fact we have a whole literature that's been generated by the pharmaceutical companies...saying we now have this thing called female sexual dysfunction and if you're not having sex and enjoying it well, you need to have our pills that we're offering you.'

'Mike', technology campaigner in interview, 2004

The persistence of pre-menstrual dysphoric disorder as a category is arguably at least in part due to marketing strategies formulated by Eli Lilly in response to patent law, and designed to bypass the lapse of the patent on Prozac by re-licensing it for a new application under the brand name of Sarafem. ${ }^{41}$ Utterly crucial to the labelling of actions as 'biocitizenship', is pre-menstrual dysphoric disorder then a biological category, or an economic and legal category? ${ }^{42}$ To encompass this citizenship behaviour under the banner 'biological' is to bypass this complexity, and to miss the many layers of meaning - biological, social, psychological, economic, legal, and so on - that can inform the frequently contested multiple and shifting identities of various citizenship projects. The reductionist focus on the biological may act to obscure the economic and other forces at play. In turn, it may then act to obscure the power flows that help to make up categories as biological or otherwise, and hence help to influence strategies for action.

Crucially, with regard to citizenship, there is a world of difference between citizens freely mobilising in relation to biotechnology, and 'citizens' actually being manipulated by the giants of biotechnology to their own ends of increasing their economic and commercial power. To posit both behaviours under the label of biocitizenship is arguably to render the term so loose that it is of scant use in illuminating citizenship behaviours and debates. Any use of the 'bio' label must be such that it does not obscure such important issues of the flow of power.

This is further illustrated in the fact that, crucially, examples Rose and Novas use tend to be ones where 'biocitizens' are mobilising over their own health and bodies, identifying themselves as part of 'disease communities' concerned about access, price, quality and availability of treatments and cures - in other words, over increasing access to the fruits of biotechnology. As Brown and Zavestoski highlight, such personal motivations are often - but not always - tied into social and political critiques as regards social equity and access. Rose and Novas refer to groups such as those mobilising around AIDS, which aim to increase access to drugs, and PXE, which are concerned with 'open source' issues and accelerating research. ${ }^{43}$ Similarly, in Seoul in February 2003, activists occupied Novartis head office in order to protest about the high cost of the anti-sarcoma drug Glivec. ${ }^{44}$ These examples are (at least relative) success stories, and the happy marriage of (even occasionally troublesome) patient group and biotechnology corporations helps to bolster claims that the citizenship activities are rightly seen as biological citizenship.

However there are many other mobilising actors whose putative 'biocitizenship' seems markedly less valid; boundaries can start to blur and conflict when issues of social justice, political economy and environment become more dominant than the discourse of medical and pharmaceutical cures. Even in Rose and Novas's own examples, one can question the usefulness of foregrounding the 'bio' in 
biocitizenship. The protests over drug access are having an impact on global governance, demonstrated by recent changes to the WTO rules intended to enable the supply of generic copies of branded drugs. ${ }^{45}$ It is essential to emphasise the importance of social justice and anti-globalisation critiques here within the broader frame of health. For instance, the People's Health Movement ${ }^{46}$ focuses predominantly on the social, political and economic aspects of health problems and their solutions, and strongly attacks globalisation's role in health crises, identifying the role of poverty as a killer and threat to health of epidemic proportions. This focus does not deny a role for medical cures but still bases its mobilisation over health on core issues of social and environmental injustice and exploitation. ${ }^{47}$ Indeed such discourses also touch policy. WHO and UNESCO have strongly advanced calls for global equity as the basis for global health, and a 2005 WHO report has critiqued genetic hype in relation to third world health outcomes. ${ }^{48}$ This example clearly shows the exercising of citizenship via a different route to that of the pro-pharmaco patient citizen.

We can see, therefore, that distilling out the biological (through an appellation of biocitizenship) may give a reductive, narrow account of the activities of citizens. Moreover there are also those who actively seek to criticise, oppose or rein in the activities of biotechnology - those who consider certain drugs to be too readily available, for example. Are these kinds of activity usefully grouped under the umbrella of biocitizenship? In considering this, it is telling that this civil society path is often far less politically successful. To give one example, the odds tend to be stacked against those pursuing legal claims against pharmaceutical companies, especially for class actions. ${ }^{49}$ Lately, following failed action relating to Vioxx, fears have been expressed that such litigation can no longer be undertaken in the UK. ${ }^{50}$

It would appear therefore, that some types of biocitizens - if we are to use the term at all - have more legitimacy and more airtime than others. Moreover, these groups' aims of reining in biotechnology make the label of 'biocitizenship' one that encompasses 'strange bedfellows', 51 who would often find themselves on quite different sides of the fence with regard to the benefits of biotechnology. This is a crucial point, for in discussing the alleged responsibilities and duties of biocitizens, as we go on to do, we must expose and articulate the goals and values that lie behind any such claims.

Biocitizenship is a broad term, allegedly, that can encompass opposition. ${ }^{52}$ But there are indications that its reductive focus on the biological may act actually to obscure debates and issues that need to be heard. We go on to explicate these points in more detail.

\section{Citizenship, reductionism and 'bio' labelling}

It is crucial to recognise that issues of identity, biological or otherwise (eg, encompassing values, or notions of community) are far more problematic than Rose and Novas seemingly allow for in their use of the label 'biocitizen'. This then prompts us to ask the question of whether such a large degree of conflict can be helpfully captured within the domain of the term 'biocitizenship'. Whilst conflict between different positions is of the essence of different citizenship claims, if Rose and 
Novas's explication of biocitizenship does not expose this conflict, this is a serious shortcoming.

As this paper will discuss, the construction, maintenance and defence of identity is complex and, in relation to biology, problematic. ${ }^{53}$ Over-using or over-privileging the 'bio' prefix is problematic, since a core criticism of the whole bioscience project from many different directions is the geneticisation and medicalisation of what are arguably social, and often normative, constructs and social issues. Similarly there are good reasons why the 'bio-labelling' of identity is reductionist, and possibly even racist, feeding into the dominance of genetic explanations of self, identity and 'human nature'. Thus, much critical discourse around 'biosubjectivities' concerns precisely this point: the rejection of the 'bio' label in favour of social explanations and solutions.

That said, in many ways genetic 'information' is impacting the identity/cultural sphere as groups and communities respond in various ways to genetic 'meanings', embracing or rejecting them, sometimes both at once. In this sense it is important to think about the 'bio' in biocitizens, in the sense that many people, in many ways, are mobilising over issues relating to biology in one form or another. But as we have seen, choosing the 'bio' label as the primary frame for any identity group is problematic with regard to the other issues that it helps to obscure. Moreover, as is already indicated and as we go on to discuss in detail, a myriad problems with equality arise within the biological. Grounding citizenship on our biology, without other considerations or safeguards, is inherently elitist, as there is simply no way of articulating criteria of inclusion that ground equal citizenship to all. We will argue that biocitizenship as articulated by Rose and Novas acts to obscure important issues about equality that urgently need attention.

Disability rights provide a clear example of identity fragmentation in this context. Someone diagnosed with a specific syndrome could identify themselves as a member of a patient group wanting cures or as a member of a disability rights group mobilising over access to treatments and a range of social provision. Such an individual could see their syndrome as core to their identity, or could reject the centrality of a biologically informed construction of their own identity. They may hold, or feel strongly antagonistic to some of these positions, and/or ambivalent about some or all of them. The core issue here is to recognise the complexity and ambivalence surrounding any construction of identity and related citizenships, because identities are multiple and also fluid. To depict even one individual, much less an entire 'disease community' or our entire species as 'biocitizens', is to unhelpfully and unnecessarily reify a complex debate. It is because of the fragmented, complex and often contradictory nature of any individual's identity, not to mention the well-identified difficulties within the concept of "collective identity ${ }^{, 54}$ in terms of what a social movement $i s,{ }^{55}$ that definitions of civil society engagement with issues of biology, bodies and identity are so problematic. The complex identity politics in the health sphere identified above highlight why the construction of identity is an ongoing problem for social movement theorists. ${ }^{56}$

Rose and Novas's notion of biological citizenship is formulated against a historical backdrop of various citizenship claims that make some reference to biology. These 
various claims act to make the question of biology a key frame through which to view questions of citizenship. But looking at the history of citizenship from a different angle, we might see that a key frame for forming citizenship projects is the recognition of biology as highly problematic and potentially divisive, or indeed, as something to be rejected entirely. This is most obvious, perhaps, in the citizenship of women.

A brief overview only is possible here. But it will serve our purpose of questioning whether simply raising the issue of biology is enough for the label 'biocitizen', or whether the rejection of biology as a politically organising concept means the 'bio' label is otiose. Mary Wollstonecraft famously argued for an extension of citizenship rights to women on the basis of a shared reason with men, ${ }^{57}$ and J. S. Mill followed her in sidelining the issue of biology. ${ }^{58}$ The liberal feminism that developed from these roots came to recognise that obscuring biology entirely might do women a disservice, and other feminisms have given biology quite a different place. Feminist views have ranged from those who wish to celebrate the uniqueness of female biology, to those who wish to minimise its significance, to those who wish to harness technology and change social structures to mould female biology. What the history of feminist thought does do though, is forcibly remind us that biology is a contested and problematic notion, not least in relation to issues of equality or inequality of citizens. ${ }^{59}$ Insofar as women have been citizens, they have always been biological citizens in the sense that their biology has been addressed in one way or another. Yet this label tells little of the struggles with biology that mark different feminisms' attempts to grapple with concrete and theoretical issues of inequality. A simple notion of 'biological citizenship' is in danger of obscuring, rather than stimulating many important debates.

\section{Biocitizenship and its values}

In considering the articulation of the notion of biocitizenship and its potential value, it is important to consider how a notion of biocitizenship might be co-opted in relation to various key citizenship debates, including the question of what responsibilities in relation to biotechnology are owed by the altruistic biocitizen. It is important to be clear that in discussing various claims that may be being made about such responsibilities, we are not necessarily suggesting that Rose and Novas themselves share these claims. Rather, our aim is to consider how their notion of biocitizenship, unless defined more robustly, might potentially be drawn upon in ways they might not intend. Our prime concern is that their notion of biocitizenship might act uncritically to foster the industrial and economic ambitions of biotechnology, despite their attention to issues surrounding 'biopiracy'. ${ }^{60}$

Talk of responsibilities of the biocitizen in relation to developments in biotechnology in particular has to be viewed against the backdrop of current considerations of responsibilities in relation to health care in general. These are present in various forms, some implicit, others overt. ${ }^{61,62}$ The general thrust of these accounts of responsibility, whilst paying some attention to systemic and organisational origins of health problems, such as the recent UK school dinners debate, ${ }^{63}$ is to encourage individuals and communities within a larger society to take on greater responsibility for health. Questions about citizenship entitlements and duties are pressing in these debates, and bring to the fore the issues of equality and fairness. ${ }^{64}$ 
Only some of the responsibilities of citizens, such as responsibilities to obey the law, and, in some jurisdictions, positive responsibilities such as the duty to vote, are clearly delineated. Others are more loosely articulated, and may not apply to all depending on one's situation in life and varying social circumstances. What is important to consider is how such duties are constructed, and exactly how citizens are exhorted to various responsibilities and acts of altruism. It is important to be clear how notions of altruism, duties, and responsibility are linked to an underlying framework of values and goals. An action can only be a duty, a responsibility, or altruistic if it carries a benefit. But benefits are disputed, and benefits in relation to medicine and biotechnology are no exception. We need to consider whether a notion of biocitizenship might channel the vision towards certain kinds of putative benefit and away from others. We also need to consider who is benefiting, and upon which citizens any associated burdens fall. Notions of citizenship do not in themselves imply equality; however, in examining the potentially problematic implications of Rose and Novas's account of biocitizenship, a key issue is whether this notion itself might act to exacerbate the unequal spread of such benefit and burden.

Following Raynor Rapp, ${ }^{65}$ Rose and Novas see new biosocial communities as 'moral pioneers' re-imagining those to whom they owe responsibility. But they also make specific claims about this: they state, for instance, that " $[t]$ he responsibility for the self now implicates both 'corporeal' and 'genetic' responsibility...now one must also know and manage the implications of one's own genome." ${ }^{\prime 66}$ It has been argued explicitly by others that we may even have a 'moral duty' to genetically enhance our children. ${ }^{67,68}$ And, as mentioned earlier, taking part in biomedical research is, arguably, itself a duty. ${ }^{69}$ This may include donating to biobanks, donating surplus ova and embryos following IVF treatment, and donating ova 'altruistically' for the specific purposes of research into so-called 'therapeutic' cloning. ${ }^{70}$ Feminist and social justice academics and campaigners have been quick to critique the 'gift' and 'duty' discourse attached to the issue of 'altruistic' egg donation for cloning, for example, ${ }^{71,72}$ and to highlight the medical risks to women. ${ }^{73,74}$

Moral pioneers and others must exercise care when they attempt to describe new responsibilities. For instance, there are many reasons for caution in relation to calls to take part in medical research. A core issue is the risks of these duties. The (unequally distributed, and disputed) risks and burdens on individuals are, or should be, taken into account in assigning duties. Also necessary is a clear and accurate analysis of how a particular, alleged duty is needed to accomplish the (unequally distributed, and disputed) goals identified from the framework of values. As we shall see, in discussions of biotechnology, these issues are frequently problematic. Alternative views of values and goals, ends and means, may undermine alleged duties of biocitizens. Here the 'green' citizenship debates outlined earlier (eg, by Barry and Dobson $^{75}$ ) are crucial to getting a fix on what is at stake here; the importance of incorporating debates on social justice and sustainability.

\section{Biocitizenship and the political economy of research}

One important consideration stems from the 'political economy of research'. The financial and other influences on people's decisions to offer themselves up as research subjects or as sources of biological material can call into question the notion of 
informed consent and indeed the notion of altruism, for altruism requires some degree of purity of motive, for public good, which is seriously muddied by the financial interests both of the biotechnology industry and of certain public 'volunteers'. Concerns about the goals of biotechnology will cast radical doubt upon its legitimacy to set out a vision of altruism for the 'biological citizen':

'The pharmaco industry is...looking at the new ways to extend their profits through their innovations, and the fact that it's led very much by that is a warning sign...It's a redefinition of what is healthy. And if you have an ongoing redefinition of normal...suddenly we will become unhealthy and with defects...we all then therefore become a market for improving ourselves.'

'Mike' in interview 2004

'I don't like the idea that by volunteering public-spiritedly...GlaxoWellcome could end up owning the patent on my cell line which poor people have to pay for.'

Member of 'disease community' in genetics workshop, European Social Forum, London, October 2004

Concerns about the relationship of research to the market cast doubt on who is really being served by advances in biotechnology. The biocitizen-as-consumer fits with the dominant discourse of biotechnology competitiveness ${ }^{77}$ in the EU 'knowledge economy':

'knowledge lies at the heart of the European Union's Lisbon Strategy to become the "most dynamic competitive knowledge-based economy in the world". 78

The programme specifically favours scientific knowledge production, in particular nanotechnology and biotechnology, exemplified via the budget expenditure for FP6/FP7. ${ }^{79}$ The emergence and implications of 'the Bioeconomy' has increasingly become the focus of academic debates, ${ }^{80}$ raising issues such as whether the Neoliberal project of the bioeconomy will solve, or exacerbate, issues of social exclusion, injustice, and environmental risk; to reiterate, issues also raised in other contexts by the green politics literature. We have shown that many of the engaged civil society actors critique the EU 'big science' knowledge economy agenda in very clear terms:

'Such an approach supports and judges research and innovation only in its ability to deliver moneymaking ventures, not whether it can make society a more sustainable and healthy place to live. ${ }^{81}$

What is the real motivation behind those who are setting agendas and values in relation to biocitizenship? Are we really being asked to do something altruistic or are we serving mammon and fostering dominant cultural values?

'[T] he reason the [TGN1412] trial $^{82}$ was happening in the UK first was probably because the UK establishment, though good by global standards, saw granting swift go/no go trial decisions as important for UK competitiveness in a field in which the UK is perceived as having a comparative advantage...'

Industry 'insider' in personal email, 25 April 2006 
The limited cast of Rose and Novas's examples, and the reductionist skew to their account, indeed the very focus on biology served by the 'bio' prefix, could all be argued to act tacitly to allow the interests of the market forces of biotechnology to operate by stealth. Citizens may not then be served well by focus on the biological if it closes down the space to frame and debate other issues and challenge implicit meanings and values - the very construction of disease, for example.

\title{
Biocitizenship and notions of 'progress'
}

These points alert us that notions of 'progress' behind research may be questioned. This questioning may be viewed as 'anti-progress', but more commonly and more accurately, it may rest upon different notions of what constitutes progress. For example, there have been a number of critiques of the notion of human 'enhancement' ${ }^{83,84,85}$ It is also noteworthy that early applications of some of this technology are for purposes which are cosmetic, commercially motivated and quite clearly, culturally loaded, and with clear gender issues. Recent media reports of the 'future promise, ${ }^{86}$ of the use of stem cells have included their use for 'safe' cosmetic breast 'enhancement' ${ }^{87}$ Is it a coincidence that one of first commercial uses of nanotech is for anti-ageing face creams (L'Oreal) $?^{88,89}$ Can 'duties' and 'responsibilities' to take part in 'cutting edge' research (eg, egg 'donation' for stem cells) possibly refer to such end-of-pipe applications and outcomes, the direction of which are dictated by 'lowest common denominator' cultural pressures and market flows?

Critiques based on medicalisation and geneticisation cast doubt upon the rationale and deleterious effects of progress cashed out in narrowly biotechnological terms:

\begin{abstract}
'[M]y life in the last two years has been a hundred percent better because I've been in housing which meets my needs and it's something as simple as being on the ground floor...we need society to accept diversity, it can't rely on us changing...they're spending huge wads of money on things, when they could be fixing the day to day problems of people that have all sorts of conditions by spending that money elsewhere.
\end{abstract}

'Sally' Disability Rights activist in interview 2004

Focus on constructions of biocitizenship where the dominant construction of health is the medical fix, influences discourses of progress. But if the STS/bioethics debate were set more broadly in relation to citizenship and health, as it is in other academic and civil society arenas as we have argued, other issues arise concerning the construction of health, and how we can be healthy. ${ }^{90}$ What would a focus on biocitizenship - as opposed to, say, health-citizenship - achieve for these urgentlyneeded debates?

\section{Biocitizenship, duties and 'choices'}

These issues can be seen further in the many problematic examples of how putative 'goods' are presented to putative biocitizens. Among these are what we might term 'crypto-duties' masquerading as choices. Pregnant women carry a disproportionate social burden here. One could argue that the context of prenatal testing, whilst overtly 
about 'informed' choice, contains various pressures towards accepting the embryonic screening tests offered them and aborting or not implanting the 'defective' foetus. What is certain is that these are difficult decisions; parents, and specifically women, may well be under pressure to 'do the right thing by society'. There are also seeming duties of biocitizenship that we cannot escape and which many have railed against. In the 'lab without walls' environmental) risk $^{92}$ from bio-experiments such as GM crops, viral vectors, genetically-modified superviruses and nano-particles) ${ }^{93,94}$ We all face being subject to increasing biosurveillance in the name of security, in the form of forensic DNA databanks, biometric scans for passports, and nanotechnological military applications such as 'smart dust'. 95

Rose and Novas acknowledge that governments will 'make up' biological citizens in ways imposed from above, but we question if their discussion and development of the concept of biocitizenship is sufficiently critical robustly to identify problems with the way bioscience is currently 'making up citizenship'. Biocitizenship needs to grapple head on with the issues of what, or how much free choice we should be allowed, and what we can legitimately be encouraged or even coerced into accepting. Currently, biocitizenship implies that certain citizenship outcomes (rights, choices, duties, goals etc) have value, whilst by their absence from the debate, it is implied that others do not.

\section{Biocitizenship and the construction and entrenchment of inequalities}

As Rose and Novas say, "not all have equal citizenship in this new biological age". 96 However, we consider that the question of inequalities needs to be foregrounded much more clearly than is apparent from Rose and Novas's explication of biocitizenship. Indeed, this 'new biological age' is in danger of actually increasing existing inequalities and inventing new ones. Rather than simply describing social phenomena, biocitizenship may act itself as a force acting to increase biologically- and technologically-conditioned inequalities.

There are many troubling examples of such inequalities in operation. In research conducted between 2003 and 2006 on UK public engagement with medical genetics, ${ }^{97}$ one of the core issues for many different groups of publics was the multiple complexities, anxieties and ambiguities around the issue of embryonic screening. In the same time period, several important public policy consultations on this topic have been launched. ${ }^{98,99,100}$ Research data from the 'Emerging Politics' project ${ }^{101}$ shows clearly that even when individual members of the public are generally supportive of the genetic testing of embryos (and many are not), they also voice concern and acknowledge deep, and often simultaneously contradictory, complexities, beyond our current remit. But these include the almost universal acknowledgement that these are difficult decisions and that women of childbearing age are on the front line of bearing this 'burden of choice'.

Controversially, prior to the outcome of a public consultation on the issue, ${ }^{102}$ the UK HFEA has recently amended a license to 'allow' women to donate ova 'altruistically' for medical research, ${ }^{103}$ and this practice already occurs elsewhere. ${ }^{104}$ Major biological differences in the ease of gamete donation between the sexes exist, and 
unless this is clearly recognised, there is a danger of unequal burdens being placed on certain (ie, female) biocitizens. ${ }^{105}$ This is especially pertinent given that women are already placed at disproportionate medical risk by having been excluded from much medical research where women, as individuals or as a class, could benefit. ${ }^{106}$

These and other possible examples of inequalities demonstrate that questions of unfair burden and benefit are pressing. It is vital that any useful notion of biocitizenship allows for full expression of these debates. Insofar as Rose and Novas's account acts to valorise biotechnology, even if inadvertently so, such important citizenship discussions will be hindered rather than eased.

Inequalities may also be created or entrenched because a certain type of patient group has much 'discursive legitimacy' with their core frames of cures, hope and progress. ${ }^{107}$ Their citizenship involves critique of current practice, but the fact that they mobilise over 'cures' acts to support the frames and agendas of the dominant paradigm generally supportive of biotechnology and of its industry. In contrast, critical or oppositional biosubjects and biosubjectivities who see themselves as under threat in some way from biotechnology have very little discursive legitimacy in the brave new 'future promise" ${ }^{108}$ world of cures and enhancement for all.

Disability Rights (DR) groups and radical feminists critical of 'enhancement' and of the implications of (embryonic) genetic screening and testing are rarely heard voices in the biosciences/bioethics debates, even when 'big hitters' like Habermas are also concerned about 'market-led eugenics'. ${ }^{109}$ Bioscience can be seen as another means through which power relations, and capitalism as a form of power relation, gets a market out of the Western rich and 'the worried well' at the expense of the poor and marginalised. If such critical voices are indeed 'biocitizens', it is in a very different way to how patient groups, who, for example, benefit from financial support from the pharmaceutical industry, are biocitizens.

\begin{abstract}
'[A]nd I've seen the presentation saying "Here is your market in the coming fifty years." Well, you've got an aging population - baby boomers who are into staying young... and they don't want to get Alzheimer's... which makes sense financially...It's a very clever strategy but it doesn't do anything for the poor, it doesn't do anything for the disabled and makes them even more beyond the pale, which is the wrong approach - it's the medicalised approach rather than a society approach and [it] doesn't do anything for the most vulnerable in society. Apart from that it will perhaps make them feel even less part of society because they're even more defective.'
\end{abstract}

'Mike' in interview, 2004

'Mike' is here concerned that certain, market-defined groups will benefit disproportionately from biotechnological developments. There are many reasons to think that 'the poor' as a group suffer disproportionate burdens and receive scant benefit from developments in biotechnology. ${ }^{110}$

Many of these concerns about inequality and access are taken up by 'New Chartists'. Their concerns include the lack of public engagement in agenda setting, ${ }^{111}$ unquantifiable risk/uncertainty in the domains of health and the environment, and the 
notion of 'enclosures', 112 exemplified in concerns over 'biopiracy' and 'biocolonialism'. Issues of ownership and commodification of 'life' and of 'the human', are taken up, together with concerns about (bio)surveillance and control. These 'New Chartists' are very unlikely to be given credence as legitimate players in terms of polity/policy and they are certainly not the type of biocitizens that Rose and Novas have in mind at all. ${ }^{113}$ In fact, as we have argued throughout, the notion of biocitizenship seems set up to exclude the already marginalised views of such participants even further.

\section{Conclusions}

Our argument has been in part empirical and in part methodological: we have shown ways in which the notion of biocitizenship articulated by Rose and Novas is explicated by reference to a limited range of examples, and based on an uncritically reductionist framework. This in turn carries the danger, albeit unintended, of an overly uncritical relationship with developments in biotechnology. Bioscience is certainly 'making up citizens' - this is an important emergent social reality - but Rose and Novas are constructing this far too optimistically. Our discussion of additional examples of citizenship, together with the use of notions, and implications, of citizenship from green politics, brings a fresh and, we hope, illuminating cast to the debate. We need now to ask if a notion of biocitizenship which overcomes these shortcomings could be articulated. Examining an idea of biocitizenship, if done critically, actually alerts us to the ways in which we are not all equal in relation to biology and to biotechnology, and to all reasons why we are subject to biotechnology rather than active citizens staking out a claim on it. Can a robust notion of biocitizenship be developed which allows room for debate and divergence, or does the 'bio' label inevitably act to tunnel our vision?

We should beware the bio-labelling of complex identities. Rather than there being a blanket biocitizenship, multiple publics are contesting power relations in multiple arenas. The many citizens identified here who are engaging, often passionately, in many different ways with these issues are certainly exercising what several key thinkers in this field have identified as important aspects of global citizenship. ${ }^{114}$ They are exercising what Dryzek has termed 'discursive turns'. ${ }^{115}$ Such 'discursive turns' need to be heard sensitively to enable conflicting claims and ambivalences full scope, and the debating stakes set as broadly and openly as possible. Otherwise, in terms of thinking about public engagement with bioscience, without urgent debate, 'biocitizenship' could become a co-opted term. Citizenship, as we said at the start, is now common currency, especially for thinking about concepts of 'global civil society'. However, as we have shown, civil society engagement with bioscience reflects widely different knowledge claims and different stakes on the construction of meaning as they exercise multiple expressions of 'epistemic citizenship'.

Whilst it must be recognised that we all inhabit multiple citizenships, the muddling of multiple identities behind the 'bio' prefix, which acts to obscure potential forms of citizenship engagement and to channel problems and their solutions in certain directions, means ultimately that any notion of biocitizenship is likely to foreground reductionist accounts. Thus, rather than simply describing a space within which a kind 
of citizenship can be articulated, it is liable to mould the kinds of thoughts and actions that can take place within that space.

It is time for us, as academics also engaged in constructing meanings, (see also John Law for an account of how research methods are always political) ${ }^{116}$ to start taking our own 'epistemic citizenship' somewhat more seriously.

\footnotetext{
${ }^{1}$ Nikolas Rose, C. Novas. 2004. Biological Citizenship. In Global Assemblages: Technology, Politics, and Ethics as Anthropological Problems. A. Ong and S. Collier, eds. Blackwell: 439-463.

${ }^{2} \mathrm{http}: / /$ www.cesagen.lancs.ac.uk/research/projects/newgentechs.htm

${ }^{3}$ R. Evans and A. Plows. Discriminating Citizens: Making Judgements about Science. Social Studies of Science (in press); R. Evans, A. Plows and I. Welsh. 2007. Towards an Anatomy of Public Engagement with Medical Genetics: Strange Bedfellows and Usual Suspects. In New Genetics, New Identities. P.
} Glasner, H. Greenslade and P. Atkinson, eds. Routledge.

${ }^{4}$ I. Welsh, A. Plows and R. Evans. In press. Another science for another world? Science and genomics at the European Social Forum 2004. In New Genetics and Society. P. Glasner and P. Atkinson, eds.

A. Plows. In press. Convergence; Nanobiotechnology and the politics of technology. In Nanotechnology; framing the field. F. Jotterand, ed.

${ }^{5}$ For example workshops on medical bioscience held during the 2004 European Social Forum. Welsh, Plows and Evans (in press), op. cit. note 4.

${ }^{6}$ A. Irwin. 1995. Citizen Science; A Study of People, Expertise and Sustainable Development. Routledge.

${ }^{7}$ A. Irwin and M. Michael. 2003. Science, Theory and Public Knowledge Maidenhead. Oxford University Press.

${ }^{8}$ F. Fischer. 2000. Citizens, Experts and the Environment: The Politics of Local Knowledge. Durham, NC and London, UK: Duke University Press.

${ }^{9}$ A. Dobson. 2003. Citizenship and the Environment. Oxford. Oxford University Press.

${ }^{10}$ J. Barry. 1999. Rethinking Green Politics. London. Sage. See also Barry's discussion of radical environmental 'resistance citizenship' in J. Barry. 2005. Resistance is Fertile: from environmental to sustainability citizenship. In Environment and Citizenship. A. Dobson and D. Bell, eds. Cambridge. MA, MIT Press.

${ }^{11}$ T. Hayward. 2005. Constitutional Environmental Rights. Oxford. Oxford University Press.

${ }^{12}$ See also A. Dobson and D Bell (eds) 2005 Environmental Citizenship, Cambridge. MA, MIT Press.

${ }^{13}$ Welsh, Plows and Evans 2007 op cit note 4.

14 T. Hayward. Ecological Citizenship: Justice, Rights and the Virtue of Resourcefulness. Environmental Politics 2006; 15(3): 435-446; and the rejoinder: A. Dobson. Ecological Citizenship: a Defence. Environmental Politics 2006; 15(3): 447-451.

${ }^{15}$ See also Ulrich Beck. 1995. Ecological Politics in an Age of Risk. Cambridge: Polity Press.

${ }^{16}$ A key point in this paper is that such links are made by social actors as well as by academics. Indeed it is precisely this point that many academics citied in this section are making.

${ }^{17}$ See for example John McMurtry. 1999. The Cancer Stage of Capitalism, Pluto Press.

${ }^{18}$ Dobson, op. cit. note 14, p. 450

${ }^{19}$ P. Brown and S. Zavestoski (eds). Social Movements in Health. Sociology of Health and Illness (special issue) 2004. 26(6).

${ }^{20}$ Brown and Zavestoski. Op. cit. note 19, pp.686.

${ }^{21}$ Rose and Novas. Op. cit. note 1, pp.441.

${ }^{22}$ See for example http://www.timesonline.co.uk/article/0,8122-1634677,00.html and http://www.ioh.uea.ac.uk/biopolitics/news.php for references to Ian Wilmut, one of the Roslin Institute's 'Dolly' cloning scientists, who is now advocating use, and 'donation' of human female eggs for therapeutic cloning purposes.

${ }^{23}$ John Harris. Scientific Research is a Moral Duty. Journal of Medical Ethics 2005; 31: 242-248.

${ }^{24}$ S. Jasanoff. 2005. Designs on Nature: Science and Democracy in Europe and the United States. Princeton University Press.

S. Jasanoff. 2005. Science and Environmental Citizenship. In Handbook of Global Environmental Politics. P. Dauvergne, ed. Edward Elgar Publishing,: 365-382.

${ }^{25}$ Rose and Novas, op. cit. note 1, pp.440. 
${ }^{26}$ Rose and Novas. Op. cit. note 1, pp.440.

${ }^{27}$ Rose and Novas. Op. cit. note 1, pp.441.

${ }^{28}$ Rose and Novas. Op. cit. note 1, pp.442.

${ }^{29}$ Rose and Novas. Op. cit. note 1, pp.440.

${ }^{30}$ Rose and Novas. Op. cit. note 1, pp.440.

${ }^{31}$ Brown and Zavestoski highlight the problems of categorising in relation to typologies of complex 'health social movements', identifying blurred boundaries between 'ideal types'. Their construction of messy and multiple loose networks draws heavily from 'standard' social movement theory and thus is a more sensitive analysis of civil society participation. A note of warning in relation to this entire arena is that researchers should not rush to define any civil society engagement as a social movement per se; a mobilising group does not a social movement make. Further, one would have to examine very thoroughly, given the many differences in patient identity frames and claims identified in this paper, the notion that there is any such thing as a UK 'patient social movement' simply because there is a plethora of mobilising patient groups.

${ }^{32}$ N. Brown and M. Michael. A Sociology of Expectations: Retrospecting Prospects and Prospecting Retro-spects, Technology Analysis and Strategic Development 2003; 15(1): 3-18.

${ }^{33}$ Rose and Novas. Op. cit. note 1, pp. 442.

${ }^{34}$ Brown and Zavestoski. Op. cit. note 19, pp.685-6.

${ }^{35} \mathrm{http}: / /$ www.prozac.com

36 http://www2.netdoor.com/ bill/prosurv/prosurv.html

${ }^{37}$ Likewise, GlaxoSmithKline (http://www.gsk.com) does not link to Paxil Protest (http://www.paxilprotest.com/) or the Seroxat Users Group (http://www.seroxatusergroup.org.uk/news.htm), both of which are patient groups mobilising to support those adversely affected by GSK's own version of Prozac, paroxetine.

${ }^{38}$ M. Day. International consumer group slates drug marketing practices. British Medical Journal 2006; 33: 14.

${ }^{39}$ Consumers International. Branding the Cure: A Consumer Perspective on Corporate Social

Responsibility, Drug Promotion and the Pharmaceutical Industry in Europe (www.consumersinternational.org).

${ }^{40}$ P. Gardner. Distorted Packaging: Marketing Depression as Illness, Drugs as Cure. Journal of Medical Humanities 2003; 24: 105-130.

${ }^{41}$ Marcia Angell. 2005. The Truth About Drug Companies: How they deceive us and what to do about it. Random House. New York.

${ }^{42}$ Indeed, adding layers of complexity to the formation of such identities, economic decisions by companies like Eli Lilly in relation to drugs like Prozac have been partly fuelled by economic pressure resulting from legal action. Many of these cases have been filed by those who question the wisdom of treating mental distress simply as a biological category.

${ }^{43}$ Rose and Novas, op. cit. note 1, pp.448 and 456.

${ }^{44} \mathrm{http}: / /$ glivec.jinbo.net/english.html.

45 Anon. WTO upholds cheaper drugs waiver. BBC News, 7 December 2005 http://news.bbc.co.uk/1/hi/business/4504922.stm.

${ }^{46}$ People's Health Movement:

http://www.phmovement.org/en/about?PHPSESSID=7ff902c8805e6157a91d662a9fa58a7a

${ }^{47}$ Dobson, 2003. op. cit. note 9.

${ }^{48}$ WHO. 2005. Genetics, genomics and the patenting of DNA: Review of potential implications for health in developing countries. Available at http://www.who.int/genomics/publications/en/index.html. ${ }^{49}$ P. Ferguson. 1996. Drug Injuries and the Pursuit of Compensation. Sweet and Maxwell. London.

${ }^{50}$ C. Dyer. English claims against Vioxx manufacturer on brink of collapse. British Medical Journal 2005; 331: 1292.

${ }^{51}$ I. Welsh, R. Evans and A. Plows. In press. Towards an Anatomy of Public Engagement with Medical Genetics: Strange Bedfellows and Usual Suspects. In New Genetics, New Identities. P. Glasner and P. Atkinson, eds. Routledge. London.

${ }^{52}$ A. Plows. 2004. Biological Citizenship and public engagement: direct action groups and the policy process. In Genetics and Society Conference on Biocitizenship. Wales Gene Park, Cardiff University, 13 October, 2004. Available at http://www.cesagen.lancs.ac.uk/resources/presentations.htm.

${ }^{53}$ A. Plows. Mapping the emergent complexity of social movement society engagement with human genetic technologies: implications for social movement theory. Meetings of Research Committee 47 of the International Sociological Association (ISA) in conjunction with Centre d'Analyse et 
d'Intervention Sociologique (CADIS) at EHESS: Paris, 11-12 June, 2004; A. Plows. In press.

Convergence: Nanobiotechnology and the politics of technology. In Nanotechnology: framing the field. F. Jotterand, ed. Springer.

${ }^{54}$ A. Melucci. 1996. Challenging Codes: Collective Action in the Information Age. Cambridge University Press. Cambridge.

${ }^{55}$ K. McDonald. From Solidarity to Fluidarity: social movements beyond 'collective identity' - the case of globalization conflicts. Social Movement Studies 2002; 1( 2): 109 - 128.

${ }^{56}$ Plows, op. cit. 53.

${ }^{57}$ Mary Wollstonecraft. 1792. A Vindication of the Rights of Woman. Penguin. Harmondsworth (1982)

${ }^{58}$ John Stuart Mill. 1869. The Subjection of Women. Virago. London (1983)

${ }^{59}$ Alison Jaggar. 1983. Feminist Politics and Human Nature. Harvester. Brighton.

${ }^{60}$ The ETC group (formerly RAFI), who coined the term 'biopiracy' have a highly developed critique of the lesser- known negative impacts that market forces combined with biotechnology are having on society http://www.etcgroup.org/en/issues/biopiracy.html.

${ }^{61} \mathrm{Eg}$, considerations suggested by the UK government about responsibilities to care for oneself in certain ways in order fully to access the health care system; Prime Minister's Strategy Unit. 2004. Personal Responsibility and Changing Behaviour: the state of knowledge and its implications for public policy. Cabinet Office. London.

${ }^{62}$ Specific and formalised accounts of responsibility are found in the Australian Federal Government's development since 2004 of Shared Responsibility Agreements (SRAs) with various Indigenous communities. Australian Government. Office of Indigenous Policy Coordination. Shared Responsibility Agreements and Regional Partnership Agreements. Available at http://www.indigenous.gov.au/sra/kit/what_are.pdf.

${ }^{63}$ See eg, the School Food Trust website: http://www.schoolfoodtrust.org.uk/?gclid=CIiO18yS9YUCFUV9EAodCRtPNQ.

${ }^{64}$ This is seen explicitly, for example, in the heated debate about the equity of SRAs with Indigenous Australians. K. Collard, H.A. D’Antoine, D.G. Eggington, B.R. Henry, C.A. Martin, G.H. Mooney. Mutual obligation in Indigenous health: can shared responsibility agreements be truly mutual? Medical Journal of Australia 2005; 182(10): 502-504.

${ }^{65}$ Rapp, R. 1999. Testing Women, Testing the Fetus: The Social Impact of Amniocentesis in America. New York. Routledge.

${ }^{66}$ Rose and Novas, op. cit. note 1, p.441.

${ }^{67}$ Taken from activist press release, 1 October 2004. https://www4.indymedia.org.uk/en/2004/10/298454.html?c=on

${ }^{68}$ Julian Savulescu. Procreative Beneficence: Why We Should Select the Best Children. Bioethics; 200(15): 413-426.

${ }^{69}$ Harris, op. cit. note 23.

${ }^{70}$ See for example M. Henderson. Cloning team calls for IVF egg donations. The Times (London), 31 May 2005 http://www.timesonline.co.uk/article/0,8122-1634677,00.html. The HFEA favours altruistic egg donation for cloning research.

${ }^{71}$ http://www.thecornerhouse.org.uk/summary.shtml?x=523542

72 Sarah Sexton. 2005. Transforming 'Waste' into 'Resource': From Women's Eggs to Economics for Women. Available at http://www.thecornerhouse.org.uk/summary.shtml?x=523542.

${ }^{73} \mathrm{http}: / /$ www.guardian.co.uk/letters/story/0,1770438,00.html.

${ }^{74}$ D. Dickenson. Commodification of Human Tissue: Implications for Feminist and Development Ethics. Developing World Bioethics 2002; 2(1): 55-63.

${ }^{75}$ Dobson, op. cit. note 9; Barry, op. cit. note 10.

${ }^{76}$ So we see how people offer themselves up for pharmaco trials; the ultimate 'biosubjects'. In London, March 2006, the now infamous TGN1412 pharmaco trial took place. See Goodyear, M. Learning from the TGN1412 trial. British Medical Journal 2006; 332: 677-678. Also see Jesse Gelsinger who died from 'routine' and non-essential gene therapy trial in US. The concept of properly 'informed consent' is becoming highly problematic.

${ }^{77}$ B. Salter and M. Jones. Regulating human genetics: the changing politics of biotechnology governance in the European Union. Health Risk and Society 2002; 4(3): 325 - 340.

${ }_{78} \mathrm{http}$ ://cordis.europa.eu/fp7/spe_programmes.htm

79 http://cordis.europa.eu/fp7/budget.htm

${ }^{80}$ See for example Mapping the Bioeconomy: The Knowledge-Based Economy and the Biosciences. Conference held at Lancaster University, 27-28 April 2006. 
${ }^{81} \mathrm{http} / / / \mathrm{www} . e s s f$ network.org/documents/ESSF_brochure.doc

${ }^{82} \mathrm{~S}$. Bhattacharya and A. Coghlan. Catastrophic immune response may have caused drug trial horror. New Scientist, 17 March 2006. Available at http://www.newscientist.com/article.ns?id=dn8863

${ }^{83}$ J. Habermas. 2003. The Future of Human Nature. Oxford. Polity Press.

${ }^{84}$ G. Wolbring. 2006. The unenhanced underclass. In P. Miller, and J. Wilsdon, eds. Better Humans? The politics of human enhancement and life extension. Demos: 122-128. Available at http://www.demos.co.uk/catalogue/betterhumanscollection/.

${ }^{85}$ Miller and Wilsdon, op. cit. note 83.

${ }^{86}$ Brown and Michael, op. cit. note 32, pp.3-18.

${ }^{87}$ W. Knight. Stem cells turn into breast implants. New Scientist, 18 Feb 2005. Available at http://www.newscientist.com/article.ns?id=dn7028. Some reports focused on medical breast reconstruction after eg, cancer surgery. The majority of press reports emphasised the potential for cosmetic breast 'enhancement' applications.

${ }^{88} \mathrm{See}$ also http://www.etcgroup.org/documents/nanoproducts_EPA.pdf.

${ }^{89} \mathrm{~S}$. Wood, R. Jones and A. Geldart. 2004. The social and economic challenges of nanotechnology ESRC report available online at http://www.esrc.ac.uk/esrccontent/DownloadDocs/Nanotechnology.pdf.

${ }^{90}$ S. Sexton. 1999. If Cloning is the Answer, What was the Question? Power and Decision-Making in the Geneticisation of Health. Available at http://www.thecornerhouse.org.uk/summary.shtml? x=51972.

${ }^{91}$ B. Szerszynski. 2005. Beating The Unbound: Political Theatre in the Laboratory Without Walls. In Performing Nature: Explorations in Ecology and the Arts. Nigel Stewart, Gabriella Giannachi, eds. Frankfurt and New York. Peter Lang.

${ }^{92}$ Risks (of certain types), of course, are in many cases being acknowledged from the top down. See, for example, the Royal Society report on nanotechnology: Royal Society. 2004. Nanoscience and nanotechnologies: opportunities and uncertainties. London. Available online at http://www.nanotec.org.uk/finalReport.htm. However, risk management, mitigation or risk identification is not the same as risk removal or a moratorium.

${ }^{93}$ S. Mayer. 2002. From genetic modification to nanotechnology: the dangers of 'sound science.In Science: can we trust the experts? T Gilland, ed.: 1-15. London. Hodder \& Stoughton.

${ }^{94}$ Mae-Wan Ho. 2003. Living With the Fluid Genome. Institute of Science and Society.

${ }^{95}$ ETC. 2003. The Big Down: Atomtech - Technologies Converging at the Nano-scale. Available at http://www.etcgroup.org/documents/TheBigDown.pdf.

${ }^{96}$ Rose and Novas, op. cit. note 1, pp.440.

${ }^{97} \mathrm{http} / / / \mathrm{www}$. lancs.ac.uk/fss/cesagen/politics/

${ }^{98}$ Human Genetics Commission. 2004. Choosing the Future: Genetics and Reproductive decisionmaking. See also http://www.hgc.gov.uk/Client/news_item.asp?Newsid=40.

${ }^{99}$ Department of Health. 2006. Responses to the consultation on the Review of the Human Fertilisation and Embryology Act. Available online at

http://www.dh.gov.uk/Consultations/ResponsesToConsultations/ResponsesToConsultationsDocumentS ummary/fs/en?CONTENT_ID=4132358\&chk=CnrKSR.

${ }^{100}$ The $2005 \mathrm{DOH}$ consultation was in fact a public review of the HFEA act in relation to use of embryos generally and of embryonic screening in particular. See

http://www.dh.gov.uk/Consultations/ResponsesToConsultations/ResponsesToConsultationsDocumentS ummary/fs/en?CONTENT_ID=4132358\&chk=CnrKSR.

${ }^{101}$ Evans et al, op. cit. note 3; homepage of the project available at http://www.lancs.ac.uk/fss/cesagen/politics/.

${ }^{102}$ HFEA. 2006. Donating eggs for research: safeguarding donors. Available at http://www.hfea.gov.uk/cps/rde/xchg/SID-3F57D79B-A850329D/hfea/hs.xsl/1417.html

${ }^{103}$ J. Dreaper and R. Buchanan. Anger over egg donation licence. BBC News 21 December 2006. Available at http://news.bbc.co.uk/1/hi/health/6197679.stm.

${ }^{104}$ Sexton, op. cit. note 71.

${ }^{105}$ J. Norsigian. Egg Donation for IVF and Stem Cell Research: Time to Weigh the Risks to Women's Health. Different Takes, Spring 2005; 33. Available at http://popdev.hampshire.edu/projects/dt/dt33.php. See also H. Pearson. Health effects of egg donation may take decades to emerge. Nature (published online), 9 August 2006. Available at http://www.nature.com/news/2006/060807/full/442607a.html.

${ }^{106}$ See eg, M.B. Blake, M. Ince, C.J. Dean. Inclusion of Women in Cardiac Research: Current Trends and Need for Reassessment. Gender Medicine 2005; 2: 71-75. 


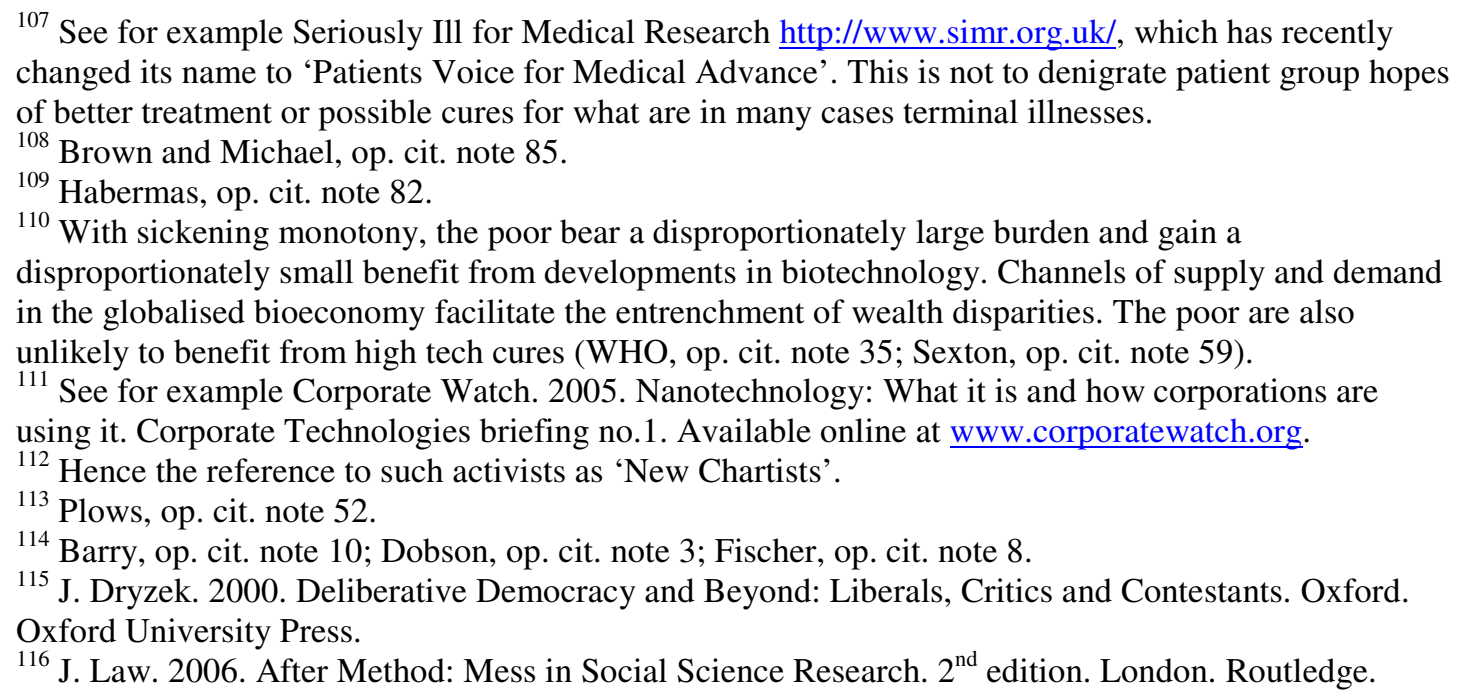

